\title{
Cattle Trampling of Crested Wheatgrass Under Short- duration Grazing
}

\author{
DAVID F. BALPH AND JOHN C. MALECHECK
}

\begin{abstract}
This paper tests 3 predictions that stem from the hypothesis that Angus heifers avoid stepping on crested wheatgrass (Agropyron cristatum) tussocks because the tussocks present an uneven surface upon which to walk: (1) hoofprints are located disproportionately more often in the open spaces between tussocks than on tussocks; (2) the disproportionality persists despite the frequency of hoof prints per unit area; and (3) the more tussocks are elevated above the surrounding substrate, the less they are trampled. The methods relate the observed and expected frequency of hoofprints on tussocks along 2 transects in a crested wheatgrass paddock. The results significantly support all 3 predictions. We conclude that under the conditions that existed, the hoof action hypothesized by some to be of benefit to short-duration grazing pastures was minimal, and so was the hoped-for destruction of standing dead vegetation that deters grazing.
\end{abstract}

Grazing livestock affect plant communities in several interrelated ways, including plant defoliation, nutrient removal and redistribution through excreta, and mechanical manipulation of soil and plant material through trampling. Although none of these effects are clearly defined, cither singly or in total, information on trampling is especially scarce. Recent reviews (Blackburn et al. 1982, Gifford and Hawkins 1978) generally associate undesirable hydrologic changes with trampling, but the relatively uniform trampling of ranges associated with intensive grazing practices (e.g., short-duration grazing) may be of value for 2 hypothesized reasons. First, the action of the cattle's hooves in breaking up the soil surface and in mixing and breaking up litter may aid plants in obtaining water and nutrients (see Savory 1978 and 1983). Second, the trampling by cattle of caespitose grasses such as crested wheatgrass (Agropyron cristatum) may break down the standing dead material within ungrazed plants (wolf plants), which is known to inhibit grazing (Willms et al. 1980). However, crested wheatgrass forms tussocks that are elevated above the surrounding substrate and present cattle with an uneven surface upon which to walk. Logically, walking on such a surface should be less desirable than walking on an even surface. Thus, we hypothesize that animals the size of cattle attempt to avoid stepping on elevated tussocks, and indeed that has been our qualitative observation. This paper tests 3 predictions that are based on this hypothesis.

1. Hoof prints are distributed disproportionately more in the open spaces between tussocks than on tussocks. If cattle avoid stepping on tussocks, fewer hoofprints will occur on tussocks and more hoofprints will occur in interstices than expected by chance.

2. The above disproportionality is independent of frequency of hoof prints per unit area (or stocking rate). If cattle avoid stepping on tussocks because the tussocks form an uneven surface to walk on, they should do so independent of the number of cattle in the area (so long as each animal can move freely).

3. Hoof prints on tussocks (should they occur) are disproportionately more frequent on the less-elevated than the more-elevated tussocks. If cattle avoid stepping on tussocks because the tussocks make the surface uneven, the more elevated the tussock the more they should avoid stepping on the tussock.

\footnotetext{
Authors are professor, Department of Fisheries and Wildlife, and professor, Department of Range Science, Utah State University, Logan, 84322.

Published with approval of the Director, Utah Agricultural Experiment Station, as Journal Paper No. 2964.

Manuscript accepted 12 September 1984.
}

This paper also seeks to measure the degree to which cattle avoid (or do not avoid) stepping on tussocks, since such information may have management implications.

\section{Methods}

We tested the predictions on spatial dispersion of hoofprints in an experimental pasture designed to investigate various plantanimal relationships that occur under short-duration grazing management. The study site was the Tintic pasture research facility, located approximately $10 \mathrm{~km}$ southwest of Eureka, Juab County, Utah. The pasture was square in shape with $10,8.5$-ha paddocks radiating from a central corral where water and salt were located (see Malechek and Dwyer 1983 for details). The predominant vegetation in the pasture was crested wheatgrass $(A$. cristatum and $A$. desertorum) from a seeding established in the early 1960 's. Prior to this study, the area had been grazed annually by cattle during May and June at a stocking rate of about 0.7 ha $\bullet \mathrm{AUM}^{-1}, \mathrm{a}$ rate we consider to be moderate grazing. In the spring of 1983, 90 Angus heifers were placed in the cell and were moved from paddock to paddock at about 3-day intervals. The overall stocking rate was maintained at the previous $0.7 \mathrm{ha} \cdot \mathrm{AUM}^{-1}$. After the cattle had been in the cell for about 50 days and upon their removal from paddock seven, we established two transects in paddock seven in areas visually assessed to support uniform stands of crested wheatgrass. The transects were perpendicular to paddock seven's radial fences, one $75 \mathrm{~m}$ (near) and the other $150 \mathrm{~m}$ (far) from the central corral. We placed a $1.0-\mathrm{m}^{2}$ quadrat frame at 5 -m intervals 10 times on the near transect and 6 times on the far transect. Within each quadrat we (1) flagged all hoofprints, (2) mapped the location of crested wheatgrass tussocks (3) categorized tussocks as being elevated $1-3,4-6$, or $>6 \mathrm{~cm}$ above the surrounding soil surface, and (4) recorded the location of each hoofprint on the tussock map. The hoofprints were easily discernible because (1) no print was older than 4 days, (2) the soil was still fluffed and moist from the spring thaw, and (3) no rain or strong wind occurred between when the prints were made and when they were documented. Tussock elevations were measured by running a straight rod in a north-south direction through the tussock immediately above the litter layer. The rod was then pressed into the litter, positioned equidistant to the soil surface on either side of the tussock, and the distance from the rod to the substrate was measured to the nearest centimeter. The procedure was repeated with the rod in an east-west direction, and the average of the measurements was used to place the tussock elevation in 1 of the 3 height classes. We used the 3 class intervals because we believed our technique lacked the precision to analyze tussock elevation to the nearest centimeter.

\section{Results}

We placed a dot matrix overlay on the 16 mapped plots and found that of the 6,310 dots covering the plots, 1,640 dots fell on the mapped tussocks ( $26 \%$ ground cover). We did not encounter any vascular plant species on the plots other than crested wheatgrass, nor did we observe crested wheatgrass plants that we did not classify as an elevated tussock. We recorded 288 hoofprints (sampling unit) on the 16 plots. Of these, 15 hoofprints were on tussocks. A "blind" interobserver reliability and observer expectancy bias check (see Balph and Balph 1983) by K. Paulin (a technician 
Table 1. Relationships between the observed and expected (random dispersion) frequency of cattle hoofprints on crested wheatgrass tussocks that vary in location and elevation above surrounding substrate.

\begin{tabular}{|c|c|c|c|c|}
\hline \multirow[b]{2}{*}{ Hoof print location } & \multirow{2}{*}{$\begin{array}{c}\text { Percent tussock } \\
\text { Cover }\end{array}$} & \multicolumn{3}{|c|}{ Number of hoofprints } \\
\hline & & Observed & Expected & Total \\
\hline $\begin{array}{l}\text { All } 1 \mathrm{~m}^{2} \text { Plots }(16) \\
\text { On Tussocks } \\
\text { On Bare Ground }\end{array}$ & 26 & $\begin{array}{r}15 \\
273\end{array}$ & $\begin{array}{r}71 \\
217\end{array}$ & 288 \\
\hline $\begin{array}{l}\text { Plots } 75 \text { m From Corral (10) } \\
\text { On Tussocks } \\
\text { On Bare Ground }\end{array}$ & 28 & $\begin{array}{r}13 \\
218\end{array}$ & $\begin{array}{r}55 \\
176\end{array}$ & 231 \\
\hline $\begin{array}{l}\text { Plots } 150 \mathrm{~m} \text { From Corral (6) } \\
\text { On Tussocks } \\
\text { On Bare Ground }\end{array}$ & 24 & $\begin{array}{r}2 \\
55\end{array}$ & $\begin{array}{l}16 \\
41\end{array}$ & 57 \\
\hline $\begin{array}{l}\text { Tussock Elevation } \\
\begin{array}{l}1-3 \mathrm{~cm} \\
4-6 \mathrm{~cm} \\
>6 \mathrm{~cm}\end{array}\end{array}$ & $\begin{array}{r}11 \\
8 \\
7\end{array}$ & $\begin{array}{r}10 \\
5 \\
0\end{array}$ & $\begin{array}{l}33 \\
21 \\
21\end{array}$ & \\
\hline
\end{tabular}

on the Tintic project) obtained 1,649 dots, 287 total prints, and 13 prints on tussocks. Since the observers were in close agreement, we used the original data for the analysis. No such check was made on the field collection procedures.

On the assumption that each hoofprint had an equal and independent chance of being at any point on the 16 plots (random dispersion), one would expect 71 hoofprints to fall on tussocks, (26\% ground cover, Table 1 ). We found only 15 hoofprints on tussocks, a significant deviation from the expected $\left(x^{2}=64.9\right.$, $P<0.0001)$. Thus, the data are consistent with the first prediction, and we conclude that the heifers tried to avoid tramping on tussocks.

Hoofprints were more than twice as common on the plots along the near transect than along the far transect (Table 1). Assuming random dispersion, one would expect 16 and 55 hoofprints to fall on tussocks on the far and near transects, respectively. We observed 2 and 13 hoofprints, respectively. The deviation from expected was significant on both transects $\left(x^{2}=17.03, P<0.0001\right.$; $x^{2}=42.1, P<0.0001$, respectively). A Test of Independence indicates that there was no difference in the avoidance of tussocks between the 2 transects $\left(x^{2}=0.42, P>0.5\right)$. The results are in agreement with the second prediction that cattle try to avoid tussocks independent of paddock use level (within constraints).

Hoof prints occurred disproportionately less often on the moreelevated than the less-elevated tussocks (Table 1). A Test of Independence between tussock elevation and frequency of trampling indicates that the relation was significant $\left(x^{2}=6.1, \mathrm{df}=2, p<0.05\right)$. These findings agree with the third prediction that cattle tramp disproportionately more often on the less-elevated than on the more-elevated tussocks. However, the animals still significantly tried to avoid even the less-elevated tussocks $\left(x^{2}=15.8, P<0.0001\right)$.

\section{Discussion}

The results of our tests are consistent with the hypothesis that cattle attempt to avoid stepping on crested wheatgrass tussocks, because the tussocks provide an uneven surface upon which to walk. These findings have implications for managing shortduration grazing systems, both in terms of where cattle step and do not step. Since cattle step in interstices where there is little litter (compared to on the tussocks), the hoof action that is thought by some people to facilitate nutrient cycling would be minimal in crested wheatgrass and perhaps other bunchgrass communities. Since cattle avoid stepping on tussocks, the hoped-for trampling of standing dead vegetation that protects crested wheatgrass from being grazed did not occur. It is our view that the stocking density necessary to trample significant numbers of tussocks would have to be quite high. Thus, it appears that not only is crested wheatgrass capable of deterring grazing by cattle, it is also capable of deterring trampling by cattle. For cattle, crested wheatgrass has the functional architecture of an arid-lands shrub (see Charley 1971). There probably is a relationship between stocking rate and rate of tussock growth in elevation from the surrounding substrate. When a pasture is first seeded to crested wheatgrass, there are no elevated tussocks. Cattle are likely to step at random with respect to plant location in such a pasture. As the plants age, elevated tussocks develop naturally because of the plant's caespitose growth form. As the elevated tussocks develop, cattle are likely to step more in interstices. Stepping in the interstices compacts the soil and makes the soil surface more prone to air and water erosion and increases the rate of tussock growth in elevation. The result is an exacerbation of the duality present in any bunchgrass community-a community comprised of pockets of biological activity above and below the ground (see West 1984) in an environment of barren, eroded ground.

\section{Literature Cited}

Balph, D.F., and M.H. Balph. 1983. On the psychology of watching birds: the problem of observer-expectancy bias. Auk 100: 755-757.

Blackburn, W.H., R.W. Knight, and M.K. Wood. 1982. Impacts of grazing on watersheds. Texas Agr. Exp. Sta. Bull. MP 1496 (College Station).

Charley, J.L. 1971. The role of shrubs in nutrient cycling, p. 182-203. In: C.M. McKell, J.P. Blaisdell, and J.R. Goodin (eds.) Wildland Shrubs -Their Biol. and Utiliz. USDA Forest Serv. Gen. Tech. Rep. INT-I. Intcrmountain Forest and Range Exp. Sta., Ogden, Utah 84401.

Gifford, G.F., and R.H. Hawkins. 1978. Hydrologic impact of grazing on infiltration: a critical review. Water Resour. Res. 14:305-313.

Malechek, J.C., and D.D. Dwyer. 1983. Short duration grazing doubles your livestock? Utah Sci. 44:32-37.

Savory, A. 1978. A holistic approach to ranch management using short duration grazing, p. 555-557. In: D.N. Hyder (ed.) Proc. 1st. Int. Range. Cong., Denver, Colo. Soc. Range Manage. Pub.

Savory, A. 1983. The Savory Grazing Method or Holistic Resource Management. Rangelands. 5:155-159.

West, N.E. 1984. Spatial pattern-functional interactions in shrub-dominated plant communities, p. 21-33. In: C.M. McKell (ed.) Shrub Biology and Utilization. Academic Press, N.Y. (in press).

Willms, W., A.W. Railey, and A. McLean. 1980. Fffect of burning or clipping Agropyron spicatum in the autumn on the spring foraging behavior of mule deer and cattle. J. Appl. Ecol. 17:69-84. 